\title{
Some studies on the wear resistance of artificial teeth in presence of amorphous $\mathrm{SiO}_{2}$ and $\mathrm{TiO}_{2}$ fillers
}

\section{(Estudos da resistência ao desgaste de dente artificial em presença de fillers amorfos $\mathrm{SiO}_{2}$ e $\mathrm{TiO}_{2}$ )}

\author{
N. Muhammad ${ }^{1}$, S. Maitra ${ }^{1}$, I. Ul Haq ${ }^{2}$, M. Farooq ${ }^{1}$ \\ ${ }^{I}$ Dept. of Chemical Engineering, Universiti Teknologi PETRONAS, Tronoh-31750, Malaysia \\ ${ }^{2}$ National Centre of Excellence in Physical Chemistry, University of Peshwar, Pakistan \\ maitrasaikat@rediffmail.com
}

\begin{abstract}
A set of composite materials were developed by blending polymethyl methacrylate (PMMA) with different amounts of micro-fine amorphous silica and titanium dioxide for application as artificial teeth. Wear resistances of these composites were measured with the help of a modified pin-on-disc tribometer and compared with commercial artificial teeth sample in the presence of artificial saliva. It has been observed that under the similar biological condition the powder fillers improved the wear resistances of the artificial teeth as compared to the commercial one under identical condition.
\end{abstract}

Keywords: amorphous silica, titania, artificial teeth, PMMA, wear resistance.

\section{Resumo}

Materiais compósitos foram desenvolvidos pela mistura de polimetil metacrilato([PMM)] com diferentes quantidades de sílica amorfa e dióxido de titânio micro-finos para aplicação como dentes artificiais. A resistência ao desgaste desses compostos foi medida com a ajuda de um tribômetro pino-sobre-disco modificado e comparado com a amostra comercial de dentes artificiais na presença de saliva artificial. Foi observado que sob condição biológica similar os compósitos melhoraram a resistência ao desgaste dos dentes artificiais, em comparação com os comerciais nas mesmas condições.

Palavras-chave: sílica amorfa, titânia, dentes artificiais, PMMA, resistência ao desgaste.

\section{INTRODUCTION}

Artificial teeth are used as substitute for defective natural teeth [1]. These are generally made up of polymeric materials, such as PMMA (poly-methyl-methacrylate). For practical applications these materials require significant wear resistance properties. Therefore researches have been going on to enhance the wear resistance properties employing different techniques for improved performances of these products [2-5]. These techniques include development of improved polymers, as well polymer-based nano-composite materials for making artificial teeth [6-10]. Some of the important work in this regard are like the following. Suzuki et al [11] evaluated six composite resins, consisting particles of different size and shape. They showed that particles of spherical shape and small size had relatively greater wear resistance and mechanical strength. Spherical particles of large size had no significant effect on wear resistance. Suzuki et al [12] further compared wear resistance of four different types of artificial teeth. The first one was filled with nano particles, the second one was filled with micro particles, in the third one cross-linking material was used and fourth one was simple acrylic teeth. Wear test of these materials revealed that nanocomposite acrylic tooth was relatively harder as compared to the others. Zeng et al [13] studied wear resistance of three composite resin teeth. The first one was filled with $47 \%$ organic filler, the second one was filled with $42 \%$ organic and inorganic filler and the third one was filled with $68 \%$ organic filler. Wear was measured in terms of volume loss and height loss. Wear induced worn surfaces of the materials were examined by SEM. It has been observed that teeth filled with higher amount of organic material exhibited greater wear resistance than the others. SEM examination revealed that the loss of filling materials was more from teeth containing less loaded teeth. Stober et al [14] examined the wear resistance of resin based teeth by body wear test machine under load of $40 \mathrm{~N}$ against $\mathrm{Al}_{2} \mathrm{O}_{3}$ ball. Natural enamel was used as a reference for this wear test. Result of their experiment revealed that there was no definite connection between wears resistance and composition of teeth. Li et al [15] studied friction and wear of natural human teeth and titanium dental materials against steel ball under load of $20 \mathrm{~N}$ for 5000 cycles by fretting machine. Result showed that titanium is one of the prospective materials for dental restoration. Titanium had good wear resistance property; biocompatibility and 
comparable weight to human skeleton. In another work Tabata et al [16] studied the wear rate of eight commercially available artificial teeth samples. Gravimetric method was used to measure wear rate of these materials and the weight were measured before and after testing by analytical balance. The difference in weight was related to wear rate of each artificial tooth. Chen et al [17] studied the effect of $\mathrm{SiO}_{2}$ nano particles on hardness and wear ability of artificial teeth. For this purpose they dispersed $\mathrm{SiO}_{2}$ nano particles in MMA monomer and compared this composite resin with conventionally heat-cured resin. Result showed that nanocomposite had better hardness and wear resistance properties than conventional heat cured resin based materials.

In this work wear resistance properties of artificial teeth developed from wear resistant polymeric composites, containing rice husk ash derived amorphous micronized silica and titanium dioxide has been studied and compared to commercial artificial teeth.

\section{EXPERIMENTAL}

Seven different artificial teeth samples available in the market were collected and their wear resistances were measured. For practical applications, the artificial teeth require high wear resistance in saliva. Artificial saliva was prepared using different salts following the procedures described in literature $[18,19]$ and its composition has been detailed in Table I. All the salts used were of analytical grade. Silica was extracted from the rice husk ash (RHA) in the form of white powder following the method described in literature [20]. In this method, rice husk ash was first treated with sodium hydroxide $(\mathrm{NaOH})$ solution under controlled condition to obtain sodium silicate $\mathrm{Na}_{2} \mathrm{SiO}_{3}$. It was further treated with sulfuric acid to precipitate $\mathrm{SiO}_{2}$. After separation of $\mathrm{SiO}_{2}$ it was thoroughly washed with deionized water to remove sodium sulphate impurity formed during the reaction. Analytical grade $\mathrm{TiO}_{2}$ (E. Merck) was used without any further treatment. The fillers $\mathrm{SiO}_{2}$ and $\mathrm{TiO}_{2}$ was characterized by scanning electron microscope (Model JEOL, JSM-5910), FT-IR spectroscopy (Shimadzu, IR Prestige-21, FTIR-8400S0, X-ray diffractometer (XRD, JEOL JDX-3532) and TGA/DTA analyzer (Diamond TG/ DTA, Perkin Elmer).

The $\mathrm{SiO}_{2}$ and $\mathrm{TiO}_{2}$ fillers were dispersed in methyl

Table I - Chemical composition of artificial saliva. [Tabela I - Composição química da saliva artificial.]

\begin{tabular}{cc}
\hline Salt & Concentration $\left(\mathrm{g} \cdot \mathrm{dm}^{-3}\right)$ \\
\hline $\mathrm{NaCl}$ & 0.4 \\
$\mathrm{KCl}$ & 0.4 \\
$\mathrm{CaCl}_{2} \cdot 2 \mathrm{H}_{2} \mathrm{O}$ & 0.795 \\
$\mathrm{NaH}_{2} \mathrm{PO}_{4} \cdot 2 \mathrm{H}_{2} \mathrm{O}$ & 0.78 \\
$\mathrm{Na}_{2} \mathrm{~S}_{9} 9 \mathrm{H}_{2} \mathrm{O}$ & 0.005 \\
$\left(\mathrm{NH}_{4}\right)_{2} \mathrm{CO}_{3}$ & 1 \\
\hline
\end{tabular}

methacrylate monomer (MMA) and it was then blended with poly-methyl-methacrylate (PMMA) for making the polymer-inorganic composites. Blending was carried out with the help of ultrasonic vibrator using specially designed Pyrex glass molds.

A modified pin-on-disc tribometer was employed for the evaluation of wear resistance properties of the commercial artificial teeth as well as the acrylic-inorganic composites. The hardened composites as well as the commercial artificial teeth were mechanically made into circular pins of equal diameters $(3 \mathrm{~mm})$ in order to fit them in the machine holder. Those pins were then subjected to wear tests, using the tribometer. In this machine, the circular pins to be tested were held in the upper static holder and subjected against moving disc of known material. All the tests were performed under constant applied load (64N) and sliding distance (180$1080 \mathrm{~m})$ in the presence of $50 \mathrm{~cm}^{3}$ of the synthetic saliva at the normal human body temperature $\left(37^{\circ} \mathrm{C}\right)$. The pin-on-disc assembly was housed in a thermostatically controlled 100 $\mathrm{cm}^{3}$ double-walled stainless steel vessel. The extent of wear of the test samples was assessed from the weights of the worn out material during the wear experiments. Wear experiments were conducted under the constant applied load of $64 \mathrm{~N}$ for various sliding distance in the presence of artificial saliva. The weight loss of the test tooth was recorded in all the wear experiments and from which the wear rate was estimated by using the following equation [21].

$$
\mathrm{W}=\delta \mathrm{m} / \mathrm{L} \rho \mathrm{F}
$$

where $\delta \mathrm{m}=$ weight loss $(\%), \mathrm{W}=$ wear rate $\left(\mathrm{mm}^{3} / \mathrm{Nm}\right), \mathrm{L}=$ sliding distance $(\mathrm{m}), \rho=$ Density and $\mathrm{F}=$ force $(\mathrm{N})$.

\section{RESULTS AND DISCUSSION}

The extracted silica powder was white in color and from the SEM analysis it can be seen that the sample was composed of irregular shaped particles in the size range 1-10 $\mu \mathrm{m}$ (Fig. 1). In the FTIR spectrum (Fig. 2) of the extracted silica, the absorption band at $3260 \mathrm{~cm}^{-1}$ and $1610 \mathrm{~cm}^{-1}$ were attributed to the stretching and bending of bonded $-\mathrm{OH}$ group respectively. The characteristic peak at $1110 \mathrm{~cm}^{-1}$ presented $\mathrm{Si}-\mathrm{O}-\mathrm{Si}$ stretching vibration of $\mathrm{SiO}_{2}$ particles. The relatively smaller small peak at $950 \mathrm{~cm}^{-1}$ was attributed to $\mathrm{Si}-\mathrm{OH}$ stretching vibration $[22,23]$. From the XRD diagram of extracted silica sample, it can be seen that the material was poorly crystalline in nature (Fig. 3). From the thermal analysis profile of the sample it can be seen that on heating in the range of $30-900{ }^{\circ} \mathrm{C}$, the as-extracted $\mathrm{SiO}_{2}$ lost about $16 \%$ of its weight at about $800{ }^{\circ} \mathrm{C}$. After heat treatment at $800{ }^{\circ} \mathrm{C}$ for $1 \mathrm{~h}$, it can be seen from the XRD diagram of the sample that it was converted to a well crystallized state (Fig. 4).

From the SEM photograph of the $\mathrm{TiO}_{2}$ sample it can be seen that it was composed of mostly nano-sized particles with narrow particle size distribution (Fig. 5). In the FTIR spectra (Fig. 6) of the sample, the absorption bands at $3200 \mathrm{~cm}^{-1}$ and $1632 \mathrm{~cm}^{-1}$ were related to the stretching and 


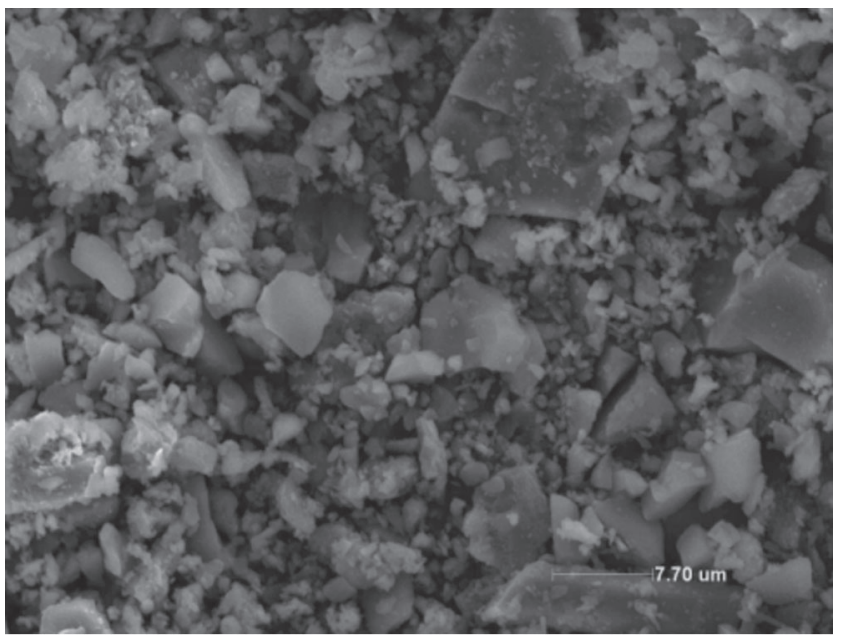

Figure 1: Scanning electron micrograph of the $\mathrm{SiO}_{2}$ particles, extracted from rice husk ash (RHA).

[Figura 1: Micrografia obtida por microscopia eletrônica de varredura de partículas de $\mathrm{SiO}_{2}$ extraidas da cinza da casca de arroz.]

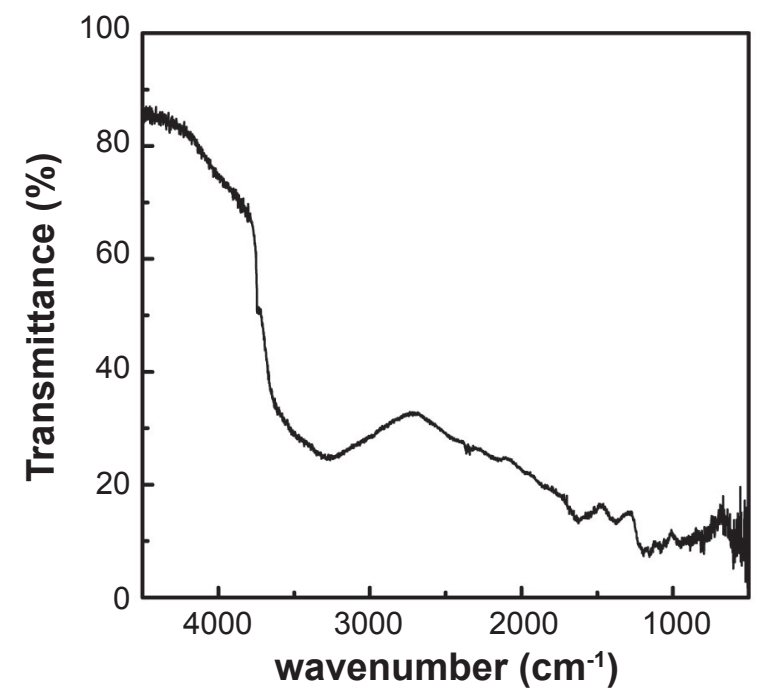

Figure 2: FT-IR spectrum of the silica particles.

[Figura 2: Espectro no infravermelho das partículas de sílica.]

bending vibrations of bonded -OH groups respectively [24]. The characteristic stretching vibration of Ti-O metal oxygen bond was observed at $912 \mathrm{~cm}^{-1}[25,26]$. In the XRD profile of the sample, the presence of the characteristic anatase peak was observed (Fig. 7).

The wear rates of different artificial teeth samples were measured in the presence of artificial saliva. Artificial teeth samples are composed of polymer PMMA as the base material. The wear rates of the samples as a function of sliding distance has been presented in Fig. 8. The polymer (PMMA)-inorganic composites were prepared by uniformly dispersing the $\mathrm{SiO}_{2}$ and $\mathrm{TiO}_{2}$ fillers in the polymer matrix during the blending process. The composites were subjected to wear tests under similar conditions. The wear rates for the different samples, containing various amounts of the filler particles were determined and compared with the average

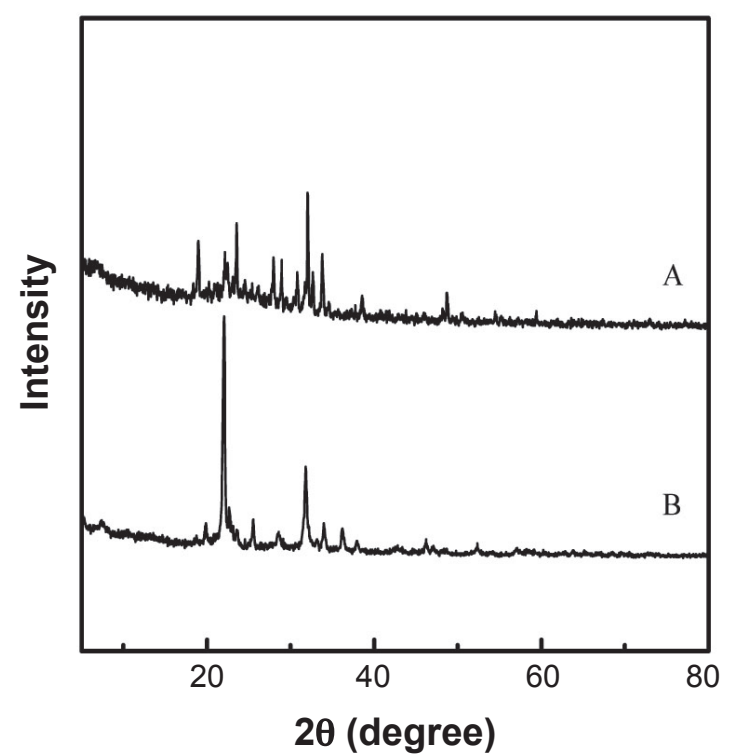

Figure 3: XRD patterns of silica obtained from RHA (A: asextracted; B: heat-treated at $800{ }^{\circ} \mathrm{C}$ ).

[Figura 3: Difratogramas de raios $X$ da sílica obtida a partir da cinza da casca de arroz (A: como extraida; $B$ : tratada termicamente a $\left.800^{\circ} \mathrm{C}\right)$.]

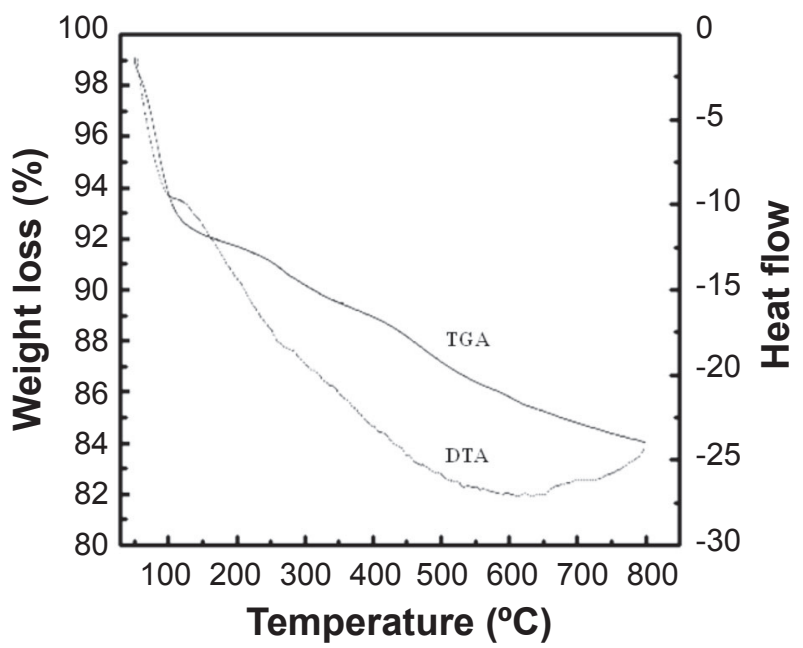

Figure 4: TGA/DTA of synthesized silica particles.

[Figura 4: Curvas ATD/ATG das partículas de sílica sintetizadas.]

wear rate of artificial teeth. The result has been presented in Fig. 9. In the present investigation, the filler amorphous $\mathrm{SiO}_{2}$ was obtained under two different conditions. These were precipitated $\mathrm{SiO}_{2}$ particles obtained at room temperature (RT$\mathrm{SiO}_{2}$ ) after drying only and silica powder obtained after heat treatment of the precipitated $\mathrm{SiO}_{2}$ at elevated temperature (HT-SiO $)_{2}$. From Fig. 9, it is apparent that loading of PMMA (poly-methyl-methacrylate) with $0.05 \mathrm{wt} \%$ of both RT- $\mathrm{SiO}_{2}$ and HT- $\mathrm{SiO}_{2}$ significantly increased its wear resistance. This indicated that uniformly dispersed particles of amorphous $\mathrm{SiO}_{2}$ effectively reinforced the PMMA (polymethyl-methacrylate) matrix and resulted in its improved wear resistance. It was also apparent from the study that the composite made with the $\mathrm{HT}-\mathrm{SiO}_{2}$ showed better wear 


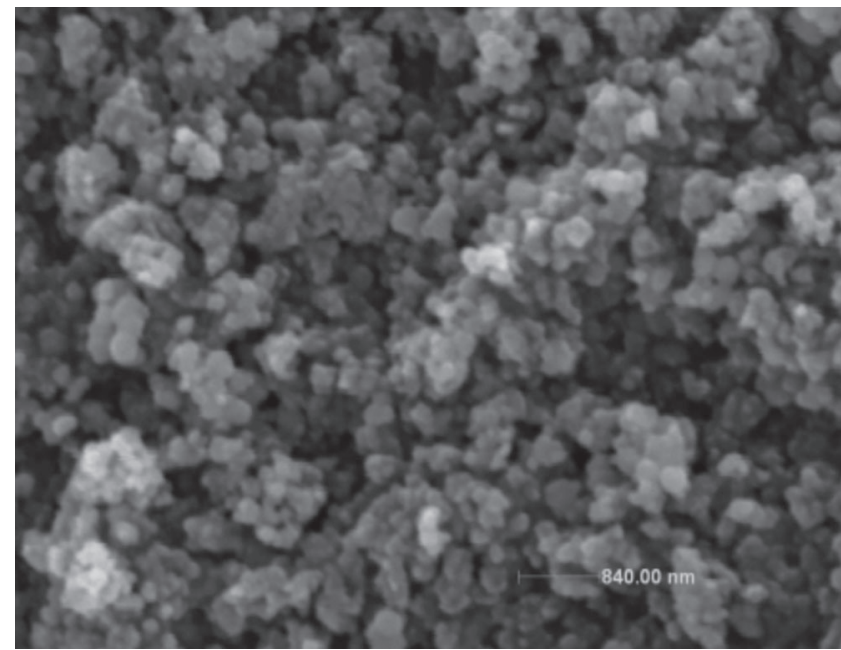

Figure 5: Scanning electron micrograph of the $\mathrm{TiO}_{2}$ sample.

[Figura 5: Micrografia obtida por microscopia eletrônica de varredura da amostra de $\mathrm{TiO}_{2}$.]

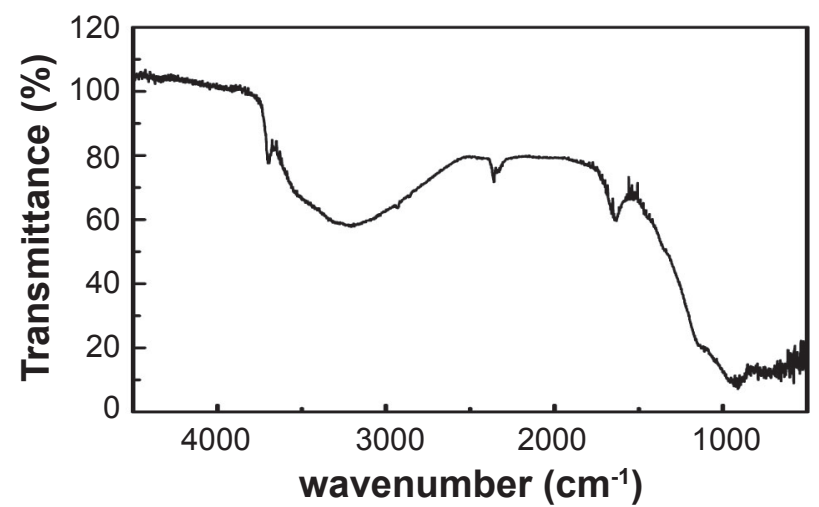

Figure 6: FT-IR spectrum of the $\mathrm{TiO}_{2}$.

[Figura 6: Espectro no infravermelho do $\mathrm{TiO}_{2}$.]

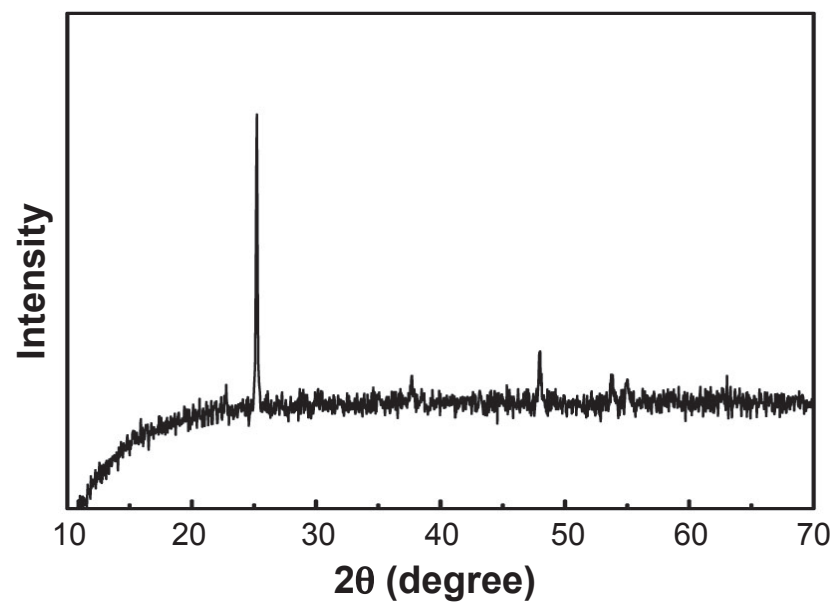

Figure 7: XRD pattern of $\mathrm{TiO}_{2}$ particles.

[Figura 7: Difratograma de raios $\mathrm{X}$ das partículas de $\mathrm{TiO}_{2}$.]

resistance as compared to the one made with $\mathrm{RT}-\mathrm{SiO}_{2}$. In the case of $\mathrm{PMMA}-\mathrm{TiO}_{2}$ composites the wear rate decreased with the increase in the filler content. For composites with $0.01 \mathrm{wt} \%$ filler $\mathrm{TiO}_{2}$ content, the wear rate was significant.

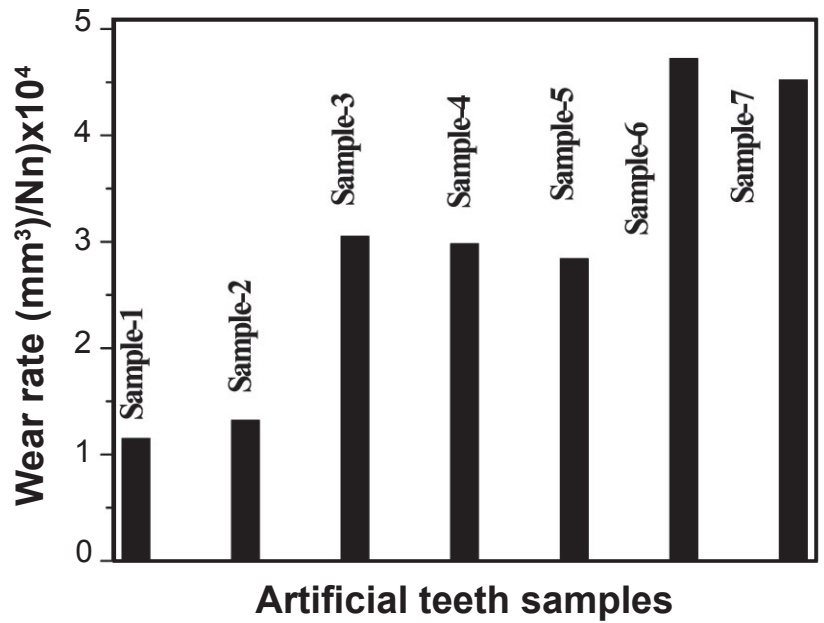

Figure 8: Wear rate of different artificial teeth sample in synthetic saliva.

[Figura 8: Taxa de desgaste de diferentes amostras de dentes artificiais em saliva artificial.]

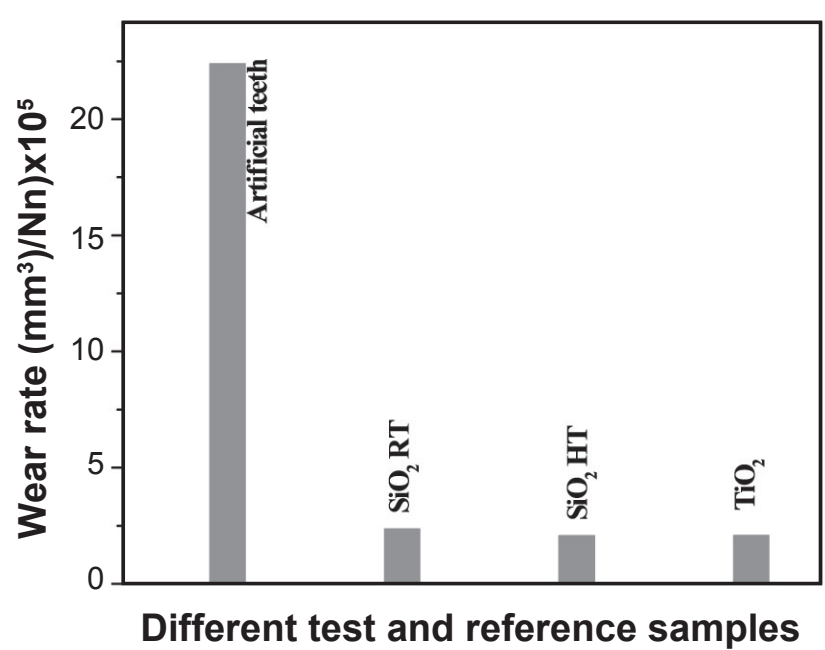

Figure 9: Average wear rates of standard artificial teeth, and PMMA composites with $\mathrm{SiO}_{2} \mathrm{RT}, \mathrm{SiO}_{2} \mathrm{HT}$ and $\mathrm{TiO}_{2}$ fillers in the presence of artificial saliva. (Wear test conditions: applied load, 64 $\mathrm{N}$; temperature $37^{\circ} \mathrm{C}$ ).

[Figura 9: Taxa de desgaste média dos dentes artificiais, e compósitos PMMA com $\mathrm{SiO}_{2} \mathrm{RT}$, $\mathrm{SiO}_{2} \mathrm{HT}$ e $\mathrm{TiO}_{2}$ na presença de saliva artificial. (Condições de ensaio: carga aplicada $64 \mathrm{~N}$; temperatura $\left.37^{\circ} \mathrm{C}\right)$.]

The wear rate did not changed significantly when the filler content was in the range of $0.01-0.03 \mathrm{wt} \%$. But the wear rate decreased significant when the $\mathrm{TiO}_{2}$ content of the composite was higher than $0.03 \mathrm{wt} \%$. Therefore, particles shape, size, chemical composition and particles contents in the composite play a major role in strengthening the polymeric matrix for improved wear resistance.

\section{SUMMARY AND CONCLUSION}

Composites suitable for use as artificial teeth were prepared by dispersing amorphous silica and titanium 
dioxide powder in PMMA polymer by blending process. The silica was extracted from rice husk ash and analytical grade $\mathrm{TiO}_{2}$ was used for this purpose. Both the fillers significantly improved the wear resistance of PMMA composites based artificial teeth by increasing the reinforcement of the matrix compared to the standard teeth sample. The reinforcement capacity of silica sample derived at high temperature was relatively more.

\section{REFERENCES}

[1] P. Lambrechts, K. Goovaerts, D. Bharadwaj, D. J. Munck, L. Bergmans, M. Peumans, V. B. Meerbeek, Wear 261 (2006) 980.

[2] A. Ekfeldt, G. Oilo, Acta Odontol. Scand. 47 (1989) 391.

[3] Y. Satoh, E. Nagai, K. Maejima, M. Azaki, R. Matsuzu, M. Matsuzu, Nihon Univ. Sch. Dent. 34 (1992) 16.

[4] S. Winkler, G. E. Monasky, J. Kwok, Prosthet. Dent. 67 (1992) 812

[5] B. L. Dahl, G. E. Carlsson, A. Ekfeld, Acta Odontol. Scand. 51 (1993) 299.

[6] J. P. Coffey, R. J. Goodkind, R. Delong, W. H. Douglas, Prosthet. Dent. 54 (1985) 273.

[7] R. E.Ogle, L. J. David, H. R. Ortman, Prosthet. Dent. 54 (1985) 67.

[8] D. J. Whitmann, J. E. McKinney, R. W.Hinman, R. A. Hesby, G. B. Pelleu, Prosthet. Dent. 57 (1987) 243.

[9] W. H. Douglas, R. Delong, M. R. Pintado, M. A. Latta, Clin. Dent. 4 (1993) 43.
[10] S. Suzuki, F. Tamura, Dent. Res. 81 (2002) 12.

[11] S. Suzuki, K. F. Leinfelder, K. Kawai, Y. Tsuchitani, Dentistry 8 (1995) 173.

[12] S. Suzuki, Prosthodont 13 (2004) 238.

[13] J. Zeng, Y. Sato, C. Ohkubo, T. Hosoi, Prosthetic Dent. 94 (2005) 453.

[14] T. Stober, T. Lutz, H. Gilde, P. Rammelsberg, Dent. Mater. 22 (2006) 243.

[15] H. Li, J. Zhang, Z. Zhou, X. Shi, Z. Li, D. Yang, Biomed. Eng. 18 (2001) 561.

[16] L. F. Tabata, G. H. Filho, C. H. Goiato, Ci. Odontol. Bras. 8 (2005) 6.

[17] W. Chen, Y. Li-Dan, Z. Yan-ping, U. X. Lian-Lai, Tianjin Med. Univ. 94 (2006) 960.

[18] A. Embong, J. Glyn-jones, A. Harrison, Dent. Mater. 3 (1987) 236.

[19] I. R. Holland, Scand J. Dent. Res. 88 (1980) 269.

[20] D. Mittal, Resonance 1 (1997) 64.

[21] S. C. Ramesh, K. S. Seshardri, Wear 255 (2003) 893.

[22] Z. Wang, Y. Zhou, Q. Yao, Y. Sun, Appl. Surface Sci. 55 (2009) 1.

[23] K. E. Girija, C. S. Latha, N. S. Kalkura, C. Subramanian, P. Ramasamy, Mater. Chem. Phys. 52 (1998) 253.

[24] G. G. Scott, Rev. Mod. Phys. 34 (1962) 102.

[25] A. Manivannan, G. Glaspell, P. Dutta, J. Clust. Sci. 19 (2008) 391.

[26] Y. Cheng, J. Guo, G. Xu, P. Cui, X. Liu, F. Liu, J Wu, Coll. Polym. Sci. 286 (2008) 1493.

(Rec. 13/05/2010, Ac. 05/08/2010) 